\title{
Rupture of a massive hydronephrotic upper pole moiety: a sequalae of mild trauma
}

\author{
Josie Colemeadow ำ , ${ }^{1}$ Karen Gordon, ${ }^{1}$ Harshawardhan Godbole, ${ }^{1}$ Hesham Safar-Aly ${ }^{2}$
}

${ }^{1}$ Urology, North Middlesex University Hospital NHS Trust, London, UK

${ }^{2}$ Radiology, North Middlesex University Hospital NHS Trust, London, UK

\section{Correspondence to} Josie Colemeadow: josie.colemeadow@nhs.net

Accepted 3 November 2020

Check for updates

(C) BMJ Publishing Group Limited 2020. No commercial re-use. See rights and permissions. Published by BMJ.

To cite: Colemeadow J, Gordon K, Godbole H, et al. BMJ Case Rep

2020:13:e238142

doi:10.1136/bcr-2020-

238142

\section{DESCRIPTION}

A 37-year-old man, with no medical history, presented acutely with severe left-sided abdominal pain following a fall on a pavement while jogging. There was gross abdominal distension with guarding in the left lumbar and upper abdominal regions on examination. Blood tests revealed acute kidney injury with a fall in glomerular filtration rate from $90 \mathrm{~mL} / \mathrm{min} / 1.73 \mathrm{~m}^{2}$ to $44 \mathrm{~mL} / \mathrm{min} / 1.73 \mathrm{~m}^{2}$. Haemoglobin level was normal.

An urgent CT urogram revealed findings consistent with rupture of a hydronephrotic upper pole of a duplexed left kidney (figures 1 and 2). The duplex kidney had duplicated ureters, giant hydronephrosis of the upper pole moiety (UPM) and megaureter, with extravasation into the retroperitoneum and peritoneal cavity and a normal left lower pole moiety (LPM) and ureter. The right kidney and collecting system were normal.

An urgent insertion of a left nephrostomy into the UPM was organised, immediately draining $600 \mathrm{~mL}$ of urine. A left-sided retroperitoneal drain was also inserted, which drained $50 \mathrm{~mL}$ of a similar fluid.

Subsequent ultrasound and MRI of the abdomen and pelvis for interval purposes and tissue characterisation confirmed a marked decrease in size of the collecting system with minimal distortion and a reduction in size of the retroperitoneal collection.

A rigid cystoscopy and retrograde study were performed on day 6 , to further delineate the anatomy of the duplex system. The LPM and associated ureter were inserted in its orthotopic position at the trigone however the now decompressed UPM and ureteric orifice were not visualised. The presentation, imaging and procedure all fulfilled the criteria for the Weigert-Meyer law. ${ }^{1}$ The Weigert-Meyer law describes how ureters in a duplicated collecting system drain. It states that with ureteral duplications, the LPM drains superolateral to the UPM, at its expected position at the trigone. The UPM, however, drains inferomedially to an ectopic location. At the time of cystoscopy, methylene blue dye injected into UPM nephrostomy was not visualised in the bladder, which, according to the law, predicts an ectopic ureter, with an inferomedial insertion and obstructing ureterocoele.

Alternatively, Stephen's ectopic pathway postulates that Weigert-Meyer's law may be broken. ${ }^{2}$ Instead of the ectopic ureter draining inferomedially to the orthotopic ureteric orifice location, rarely it may drain superomedially to it.

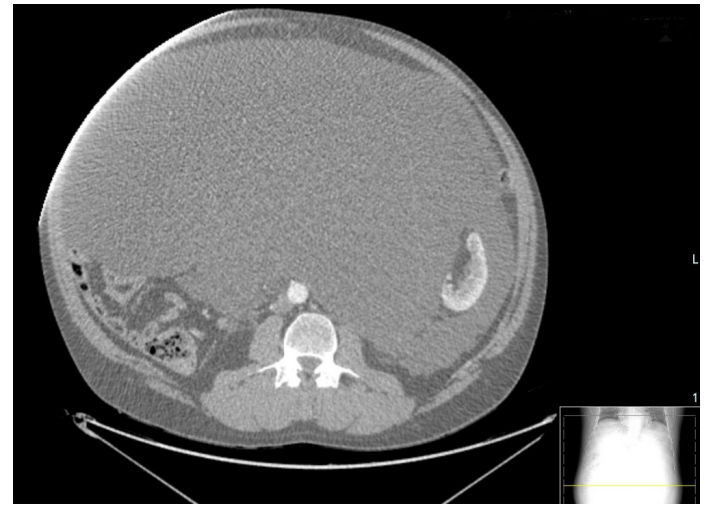

Figure $1 \mathrm{CT}$ abdomen/pelvis demonstrating massively dilated upper moiety renal pelvis with retroperitoneal and intraperitoneal fluid consistent with rupture.

A follow-up CT urogram demonstrated a normal LPM however the UPM was non-functioning with a thin cortex and no contrast flow through the renal pelvis to ureter. A urology multidisciplinary team discussion recommended a dimercaptosuccinic acid (DMSA) scan to assess the differential function of the left and right kidney along with the two moieties of the left kidney to decide whether the patient can safely proceed to left upper polar heminephroureterectomy. The DMSA scan demonstrated a photopenic appearance of the upper third of the left kidney consistent with poor function. $\mathrm{He}$ has subsequently been referred to a tertiary centre.

This is the first report, to our knowledge, of a ruptured duplex system following abdominal trauma.

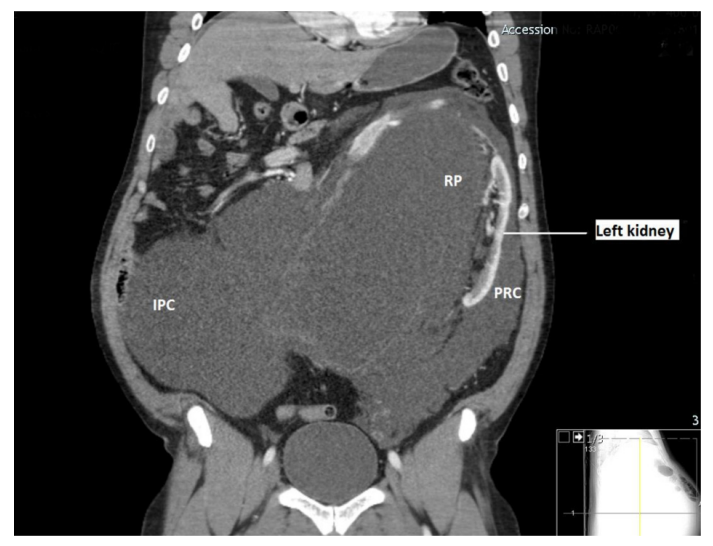

Figure $2 \mathrm{CT}$ abdomen/pelvis demonstrating massively dilated upper moiety renal pelvis (RP) with perirenal collection (RPC) and intraperitoneal collection (IPC) consistent with rupture. 


\section{Learning points}

The Weigert-Meyer rule applies to this case study. It states that the upper moiety ureter drains inferomedially to the lower pole moiety, often to an ectopic location.

- The ureter of the upper pole moiety frequently ends as a ureterocoele, which can obstruct the collecting system leading to hydronephrosis and hydroureter. This can present with symptoms relating to mass effect.

- Rarely, mild abdominal trauma can lead to rupture of a grossly hydronephrotic duplex collecting system.

Twitter Josie Colemeadow @josiecolemeadow

Contributors JC: primary author and editing of document following reviews. Care for patient during admission. KG: review of manuscript and alterations. Care for patient during admission. HG: review of manuscript and alterations. Care for patient during admission. HS-A: review of manuscript. Care for patient during admission.

Funding The authors have not declared a specific grant for this research from any funding agency in the public, commercial or not-for-profit sectors.

Competing interests None declared.

Patient consent for publication Obtained.

Provenance and peer review Not commissioned; externally peer reviewed.

ORCID iD

Josie Colemeadow http://orcid.org/0000-0002-4791-7508

\section{REFERENCES}

1 Esfahani SA, Close C, Yousefzadeh DK. Side-to-side and interpolar renal duplications: the nonpolar variety. Int Urol Nephrol 2013:45:333-8.

2 Duicu C, Kiss E, Simu I, et al. A rare case of double-system with ectopic ureteral openings into vagina. Front Pediatr 2018;6:176.

Copyright 2020 BMJ Publishing Group. All rights reserved. For permission to reuse any of this content visit

https://www.bmj.com/company/products-services/rights-and-licensing/permissions/

BMJ Case Report Fellows may re-use this article for personal use and teaching without any further permission.

Become a Fellow of BMJ Case Reports today and you can:

- Submit as many cases as you like

- Enjoy fast sympathetic peer review and rapid publication of accepted articles

- Access all the published articles

Re-use any of the published material for personal use and teaching without further permission

Customer Service

If you have any further queries about your subscription, please contact our customer services team on +44 (0) 2071111105 or via email at support@bmj.com.

Visit casereports.bmj.com for more articles like this and to become a Fellow 